\title{
The roles of prostaglandins in vertebrate ovulation
}

\author{
Takayuki Takahashi*, Akane Hagiwara and Katsueki Ogiwara \\ Laboratory of Reproductive and Developmental Biology, Hokkaido University, Japan
}

Submission: March 12, 2018; Published: April 30, 2018

*Corresponding author: Takayuki Takahashi, Laboratory of Reproductive and Developmental Biology, Faculty of Science, Hokkaido University, Sapporo 060-0810, Japan, Tel: +81-11-706-3522, Fax: +81-11-706-3522; Email: ttakaha@sci.hokudai.ac.jp

\begin{abstract}
Prostaglandins are one of the biochemicals that have received much attention in the study of vertebrate ovulation. This review describes recent advances in the understanding of the roles of prostaglandins in vertebrate ovulation.

Keywords: Vertebrate; Ovulation; Prostaglandin; Oocyte maturation; Cumulus-oocyte complex expansion; Follicle rupture; Gonadotropin; Mammalian; Periovulatory; Postovulatory follicles; Cumulus-oocyte; Hyaluronan; Teleost fish; Cytoskeletone; Ovulating follicles; Rupture; Nonmammalian vertebrates; Vertebrate ovulation; Endoperoxide; Antrum; Cumulus

Abbreviations: LH: Luteinizing Hormone; PG: Prostaglandin; COC: Cumulus-Oocyte Complex; Ptgs: Prostaglandin-Endoperoxide Synthase; PGE2: Prostaglandin E2; PGF2 $\alpha$ : Prostaglandin F2 $\alpha$; Ptger2, Prostaglandin E2 Receptor Subtype 2; Ptger4b: Prostaglandin E2 Receptor Subtype 4b
\end{abstract}

\section{Introduction}

Ovulation in vertebrates is triggered by the preovulatory surge of gonadotropin luteinizing hormone (LH). After the LH surge, the oocyte undergoes final maturation, and phenotypic changes occur in the somatic cells, granulosa cells and the theca cells, surrounding the oocyte. Prostaglandins (PGs) are recognized as an important mediator for LH-surged ovulation in vertebrate animals. Many studies have been conducted using mammalian species with attention directed to PGs to define their roles in ovulation [1-4]. In addition, a significant advancement of the roles of PGs in teleost ovulation has been accomplished in recent years [5]. In this review, the current knowledge on the roles of PGs in the process of teleost and mammalian ovulation is summarized.

\section{PGs involved in vertebrate ovulation}

In mammalian ovaries, prostaglandin E2 (PGE2) is involved in the process of ovulation of periovulatory follicles [6,7], while prostaglandin F $2 \alpha$ (PGF2 $\alpha$ ) plays a critical role in the luteolytic events of postovulatory follicles [4]. In teleosts, both PGE2 and PGF2 $\alpha$ serve as a regulator of ovulation although the molecular species of PG functional in fish ovulation varies in different species [5].

\section{The roles of PGE2 in the ovulatory process in mammals}

LH surge induces the ovulatory process in the follicles that are destined to ovulate. In mammals, the ovulatory process includes the expansion of the cumulus-oocyte complex (COC), oocyte maturation, and follicle rupture. COC is essential not only for the release of the oocyte through the ruptured follicle envelope during ovulation but also fertilization and the development of early-stage embryos. Mice lacking the gene encoding prostaglandin-endoperoxide synthase-2 (Ptgs2, also known as cyclooxygenase-2) and the PGE2 receptor Ptger2 [1,3] exhibited impaired COC expansion and a decrease in ovulation number [2]. A characteristic feature of COC expansion is the formation of a highly complex extracellular matrix in the cumulus cells and mural cells surrounding the antrum. Among the major components critically involved in the expansion of COC, the expression of glycosaminoglycan hyaluronan synthase-2 (HA2 ), the enzyme responsible for hyaluronan synthesis, and the hyaluronan-binding protein TNF-a-stimulated gene 6 (TSG-6) is demonstrated to be the downstream event of PGE2/Ptger2 activation [8,9]. In addition, the involvement of PGE2/Ptger2 signaling in the process of oocyte maturation in mammals have been documented [10-12]. However, the functions of PGE2 in follicle rupture in mammals are unclear at present.

\section{The roles of PGE2 in the ovulatory process in teleosts}

PGF $2 \alpha$ plays a role in mediating ovulatory actions of the LH surge in many teleost fish [5], while PGE2 serves as LH-induced key ovulatory events in some teleosts, including medaka $[13,14]$. The possible involvement of PGs in both oocyte maturation and follicle rupture in teleosts was repeatedly reported [5]. However, the mechanism of how PGs are involved in the process remains to be answered. The role of PGs in follicle rupture during ovulation was intensively investigated using medaka $[15,16]$, which serves as a good vertebrate model for ovulation study [17-20]. The results of these studies indicate that in this fish, PGE2/Ptger4b 


\section{Global Journal of Reproductive Medicine}

signaling is activated in the follicle cells of ovulating follicles at the time of ovulation and that the receptor activation then induces intracellular actin cytoskeletone rearrangement of the cells $[5,16]$.

\section{Conclusion}

Previous studies have revealed the differences and similarities in the roles for PGs in mammalian and teleost ovulation. Impact of PGs on oocyte maturation is conserved from teleosts to mammals. In teleosts, PGs also play an important role in the rupture of ovulating follicles. Ovulation is often described as a process of squeezing the oocyte through a rupture in the surrounding the tissue [21]. This notion implies that ovulation is comprised of two phenomena involving enzymatic degradation of follicle wall and contraction of the outer somatic cell layer surrounding the oocyte. This two-phenomenon hypothesis was described for the first time by Schochet [22] for mammalian ovulation, but is undoubtedly applicable to ovulation of nonmammalian vertebrates, including teleost fish. The role of PGs in teleost ovulation is probably to facilitate the release of oocytes from the follicles by inducing the contraction of the somatic cell layer. Further comparative studies using various animals will help understand the differences and similarities in the roles of PGs in vertebrate ovulation.

\section{Acknowledgement}

This work was supported by a Grant-in-Aid for Scientific Research $16 \mathrm{H} 04810$ from the Ministry of Education, Culture, Sports, Science and Technology of Japan.

\section{References}

1. Hizaki H, Segi E, Sugimoto Y, Hirose M, Saji T, et al. (1999) Abortive expansion of the cumulus and impaired fertility in mice lacking the prostaglandin E receptor subtype EP(2). Proc Natl Acad Sci USA 96(18): 10501-10506.

2. Davis BJ, Lennard DE, Lee CA, Tian HF, Morham SG, et al. (1999) Anovulation in cyclooxygenase-2-deficient mice is restored by prostaglandin E2 and interleukin-1 $\beta$. Endocrinology 140(6): 26852695.

3. Tilley SL, Audoly LP, Hicks EH, Kim HS, Flannery PJ, et al. (1999) Reproductive failure and reduced blood pressure in mice lacking the EP2 prostaglandin E2 receptor. J Clin Invest 103(11): 1539-1545.

4. Sugimoto Y, Inazumi T, Tsuchiya S (2015) Roles of prostaglandin receptors in female reproduction. J Biochem 157(2): 73-80.

5. Takahashi T, Hagiwara A, Ogiwara K (2018) Prostaglandins in teleost ovulation: A review of the roles with a view to comparison with prostaglandins in mammalian ovulation. Mol Cell Endocrinol 461(5): 236-247.

6. Espey LL, Richards JS (2006) Ovulation. In: Neill JD (Eds), Physiology of Reproduction ( $3^{\text {rd }}$ edn), Academic Press, Amsterdam, USA, pp. 425474
7. Duffy DM (2015) Novel contraceptive targets to inhibit ovulation: the prostaglandin E2 pathway. Hum Reprod Update 21(15): 652-670.

8. Ochsner SA, Russell DL, Day AJ, Breyer RM, Richards JS (2003) Decreased expression of tumor necrosis factor- $\alpha$-stimulated gene 6 in cumulus cells of the cyclooxygenase-2 and EP2 null mice. Endocrinology 144(3): 1008-1019.

9. Richards JS (2005) Ovulation: new factors that prepare the oocyte for fertilization. Mol Cell Endocrinol 234(1-2): 75-79.

10. Downs SM, Longo FJ (1983) Prostaglandins and preovulatory follicular maturation in mice. J Exp Zool 228(1): 99-108.

11. Takahashi T, Morrow JD, Wang H, Dey S (2006) Cyclooxygenase-2derived prostaglandin E2 directs oocyte maturation by differentially influencing multiple signaling pathways. J Biol Chem 281(48): 3711737129.

12. Marei WF, Abayasekara DR, Wathes CDC, Fouladi Nashta AA (2014) Role of PTGS2-generated PGE2 during gonadotrophin induced bovine oocyte maturation and cumulus cell expansion. Reprod Biomed Online 28(3): 338-400.

13. Fujimori C, Ogiwara K, Hagiwara A, Rajapakse S, Kimura A, Takahashi $\mathrm{T}$ (2011) Expression of cyclooxygenase-2 and prostaglandin receptor EP4b mRNA in the ovary of the medaka fish, Oryzias latipes: Possible involvement in ovulation. Mol Cell Endocrinol 332(1-2): 67-77.

14. Fujimori C, Ogiwara K, Hagiwara A, Takahashi T (2012) New evidence of the involvement of prostaglandin receptor EP4b in ovulation of the medaka, Oryzias latipes. Mol Cell Endocrinol 362(1-2): 76-84.

15. Hagiwara A, Ogiwara K, Katsu Y, Takahashi T (2014) Luteinizing hormone-induced expression of Ptge4b, a prostaglandin E2 receptor indispensable for ovulation of the medaka Oryzias latipes, is regulated by a genomic mechanism involving nuclear protestin receptor. Biol Reprod 90(6): 1-14.

16. Ogiwara K, Takahashi $\mathrm{T}$ (2016) A dual role for melatonin in medaka ovulation: ensuring prostaglandin synthesis and actin cytoskeleton rearrangement in follicle cells. Biol Reprod 94(3): 64.

17. Ogiwara K, Takano N, Shinohara M, Murakami M, Takahashi T (2005) Gelatinase A and membrane-type matrix metalloproteinases 1 and 2 are responsible for follicle rupture during ovulation in the medaka. Proc Natl Acad Sci USA 102(24): 8442-8447.

18. Ogiwara K, Minagawa K, Takano N, Kageyama T, Takahashi T (2012) Apparent involvement of plasmin in early stage follicle rupture during ovulation in medaka. Biol Reprod 86(4): 113.

19. Ogiwara K, Hagiwara A, Rajapakse S, Takahashi T (2015) The role of urokinase plasminogen activator and plasminogen activator inhibitor-1 in follicle rupture during ovulation in the teleost medaka. Biol Reprod 92(1): 10.

20. Ogiwara T, Takahashi $T$ (2017) Involvement of the nuclear progestin receptor in LH-induced expression of membrane type 2-matrix metalloproteinase required for follicle rupture during ovulation in the medaka, Oryzias latipes. Mol Cell Endocrinol 450: 54-63.

21. Schroeder PC, Talbot P (1985) Ovulation in the animal kingdom: A review with an emphasis on the role of contractile processes. Gamete Res 11: 191-211.

22. Schochet SS (1916) A suggestion as to the process of ovulation and ovarian cyst formation. Anat Rec 10: 447-457. 
CC (i) This work is licensed under Creative (c) BY DOI: 10.19080/GJORM.2018.04.555639

\section{Your next submission with Juniper Publishers} will reach you the below assets

- Quality Editorial service

- Swift Peer Review

- Reprints availability

- E-prints Service

- Manuscript Podcast for convenient understanding

- Global attainment for your research

- Manuscript accessibility in different formats ( Pdf, E-pub, Full Text, Audio)

- Unceasing customer service

Track the below URL for one-step submission https://juniperpublishers.com/online-submission.php 